\title{
Synthesis, Characterization, Mössbauer Parameters, and Antitumor Activity of Fe(III) Curcumin Complex
}

\author{
Mutasim Ibrahim Khalil, Aisha Mohamed Al-Zahem, and Maha Hamad Al-Qunaibit
}

Chemistry Department, King Saud University, Riyadh 11451, Saudi Arabia

Correspondence should be addressed to Mutasim Ibrahim Khalil; mkhalil@ksu.edu.sa

Received 13 December 2012; Revised 4 March 2013; Accepted 4 March 2013

Academic Editor: Giovanni Natile

Copyright ( 2013 Mutasim Ibrahim Khalil et al. This is an open access article distributed under the Creative Commons Attribution License, which permits unrestricted use, distribution, and reproduction in any medium, provided the original work is properly cited.

Curcumin-Fe(III) complex was prepared from $\mathrm{Fe}\left(\mathrm{NO}_{3}\right)_{3} \cdot 9 \mathrm{H}_{2} \mathrm{O}$ precursor and curcumin by refluxing a slightly basic methanolic solution of their mixture with the objective of investigating its cytotoxicity. The enol form of curcumin ligand was established by FTIR, UV/Vis, ${ }^{1} \mathrm{H}$ NMR, and ${ }^{13} \mathrm{C}$ NMR spectroscopy. The as-prepared product was characterized by elemental analysis, FTIR, UV, and Mössbauer spectroscopic techniques. An octahedral high-spin Fe(III) complex was obtained, $\delta, 0.37 \mathrm{mms}^{-1}$; Q.S., $0.79 \mathrm{mms}^{-1}$; no magnetic relaxation was observed at liquid $\mathrm{N}_{2}$ temperature, neither reduction of $\mathrm{Fe}(\mathrm{III})$. The tested cytotoxicity of the asprepared complex on four cancer cell lines indicated inhibition of the curcumin activity upon complexing with iron.

\section{Introduction}

The $\beta$ diketone curcumin and curcuminoids (1,7-diaryl1,6-heptadiene-3,5-diones) which are a group of naturally occurring 1,3-diketones have received considerable attention in the last few decades. This is due to the fact that they possess antitumor [1-3] and antioxidant effects [4] and have a good potential for metal ions complexation.

It has been reported that metal complexation alters the various physiological properties especially the cytotoxic and antitumor activities of many naturally occurring compounds [5]. It is demonstrated that the coordination of metal ions, for example, $\mathrm{Cu}(\mathrm{II}), \mathrm{Mn}(\mathrm{II}), \mathrm{Au}(\mathrm{III})$, and so forth, with bioactive ligands can actually improve the pharmaceutical activity of drugs $[6,7]$.

The Mössbauer metal isotopes, for example, $\mathrm{Fe}, \mathrm{Au}, \mathrm{Ru}$, Ir, and so forth, form stable complexes with the curcumin ligand $[8,9]$. Tonnesen and Greenhill $[8]$ have reported the reduction of $\mathrm{Fe}(\mathrm{III})$ to $\mathrm{Fe}(\mathrm{II})$ in the presence of curcumin. However, there is no published Mössbauer data on such complexes that could shed light on iron moiety and the correlation between the magnetic, symmetry, and oxidation states of metal ions in such chelates and their biological activity. In this paper we report the Mössbauer data of $\mathrm{Fe}(\mathrm{curc})_{3}$ complex, compare it to the well-known $\mathrm{Fe}(\mathrm{acac})_{3}$ data, and identify and correlate oxidation state of the central iron metal ion, magnetic relaxation, and structural symmetry of the as-prepared complex to its antitumor cytotoxicity on four cancer cell lines.

\section{Experimental}

2.1. Chemicals and Materials. All solvents (Sigma-Aldrich) were reagent grades and were used without further purifications. Curcumin (Sigma-Aldrich and Acros Organics) was extensively analyzed and the Sigma sample form was established. $\mathrm{Fe}\left(\mathrm{NO}_{3}\right)_{3} \cdot 9 \mathrm{H}_{2} \mathrm{O}(\mathrm{BDH})$ laboratory reagent was used.

2.2. Analytical Instruments. FTIR spectra were recorded in the solid state ( $\mathrm{KBr}$ pellets) in the range $250-4000 \mathrm{~cm}^{-1}$ using a Shimadzu FTIR-8400S, Prestige-21 spectrophotometer. UV/Vis spectra were recorded on a Shimadzu UV-1650 PC spectrophotometer in the range $200-800 \mathrm{~nm} .{ }^{1} \mathrm{H}$ and ${ }^{13} \mathrm{C}$ NMR were recorded on a Jeol Eclipse $400 \mathrm{MHz}$ instrument using TMS external standard (chemical shift $\delta$ in ppm). C, $\mathrm{H}, \mathrm{N}, \mathrm{O}$, and iron analysis was carried at Mikroanalytisches Labor Pascher, Remagen Laboratories. The ${ }^{57} \mathrm{Fe}$ Mössbauer absorption spectra were recorded at $295 \mathrm{~K}$ and $78 \mathrm{~K}$ using 
TABLE 1: Mössbauer parameters of $\mathrm{Fe}(\mathrm{acac})_{3}$ and $\mathrm{Fe}(\mathrm{curc})_{3}$ complexes.

\begin{tabular}{lccc}
\hline Sample/temperature & I.S. $(\mathrm{mm} / \mathrm{s})$ & Q.S. $(\mathrm{mm} / \mathrm{s})$ & $\Gamma(\mathrm{mm} / \mathrm{s})$ \\
\hline $\mathrm{Fe}(\text { Curcumin })_{3}(295 \mathrm{~K})$ & 0.37 & 0.79 & 0.51 \\
$\mathrm{Fe}(\text { Curcumin })_{3}(78 \mathrm{~K})$ & 0.46 & 0.96 & 0.62 \\
$\mathrm{Fe}(\mathrm{acac})_{3}(295 \mathrm{~K})$ & 0.36 & 0.82 & 0.49 \\
$\mathrm{Fe}(\mathrm{acac})_{3}(78 \mathrm{~K})$ & 0.44 & 0.94 & 0.33 \\
\hline
\end{tabular}

a Harwell Mössbauer spectrometer. The spectra were refined using least square method.

2.3. Cytotoxic Activity Measurements. Cytotoxic activity measurements were carried out in Cairo Cancer Research Center, Egypt. The determination and counting of viable cells were achieved by adding $50 \mu \mathrm{L}$ of $0.05 \%$ trypan blue solution to $50 \mu \mathrm{L}$ of the single cell suspension. The cells were examined under the inverted microscope using the hemocytometer. Nonstained (viable) cells were counted and the following equation was used to calculate the cell count $/ \mathrm{mL}$ of cell suspension:

viable cells $/ \mathrm{mL}$

$$
=\frac{\text { number of cells } 4 \text { quarters } \times 2 \text { (dilution factor) } \times 104}{4} .
$$

The cells were then diluted to give the concentration of single cell suspension required for each experiment.

The percentage of cell survival was calculated as follows:

(i) survival fraction $=$ O.D. $($ treated cells)/O.D. (control cells),

(ii) the $\mathrm{IC}_{50}$ values are the concentrations of thymoquinone required to produce 50 inhibitions of cell growth. The experiment was repeated 3 times for each cell line.

2.4. Synthesis of $\mathrm{Fe}(\mathrm{III})(\mathrm{acac})_{3}$ and $\mathrm{Fe}(\mathrm{III})(\mathrm{curc})_{3}$ Complexes. The $\mathrm{Fe}(\mathrm{III})(\mathrm{acac})_{3}$ complex was prepared by dissolving $2.1 \mathrm{~g}$ of finely ground iron(III) chloride hexahydrate in $50 \mathrm{~mL}$ distilled water in a $250 \mathrm{~mL}$ beaker. $0.1 \mathrm{M} \mathrm{NaOH}$ solution was added dropwise until the brown precipitate that was formed is completely redissolved. $2.4 \mathrm{~mL}$ of acetylacetone in $20 \mathrm{~mL}$ ethanol was then added dropwise with continuous magnetic string followed by the addition of $3.3 \mathrm{~g}$ sodium acetate in $15 \mathrm{~mL}$ distilled water. The whole mixture was heated in a water bath to $\approx 80^{\circ} \mathrm{C}$ and maintained at that temperature for $1 \mathrm{~h}$ with rapid stirring. The solution was then cooled to room temperature and cooled further in an ice bath. The red crystals were vacuum filtered and dried in a desiccator $[10,11]$. The complex was characterized by elemental analysis, (found; C\%, 50.6; H\%, 6.3; yield\%, 72), FTIR spectroscopy (see supporting information available online at http://dx.doi.org/10.1155/2013/982423), and Mössbauer spectroscopy, Figure 1 and Table 1 . Fe(III)(curc) 3 complex was prepared by refluxing for $3 \mathrm{~h}$ in a methanolic mixture solution of $0.6 \mathrm{mmol}$ curcumin and $0.2 \mathrm{mmol} \mathrm{Fe}(\mathrm{III})\left(\mathrm{NO}_{3}\right)_{3} \cdot 9 \mathrm{H}_{2} \mathrm{O}$

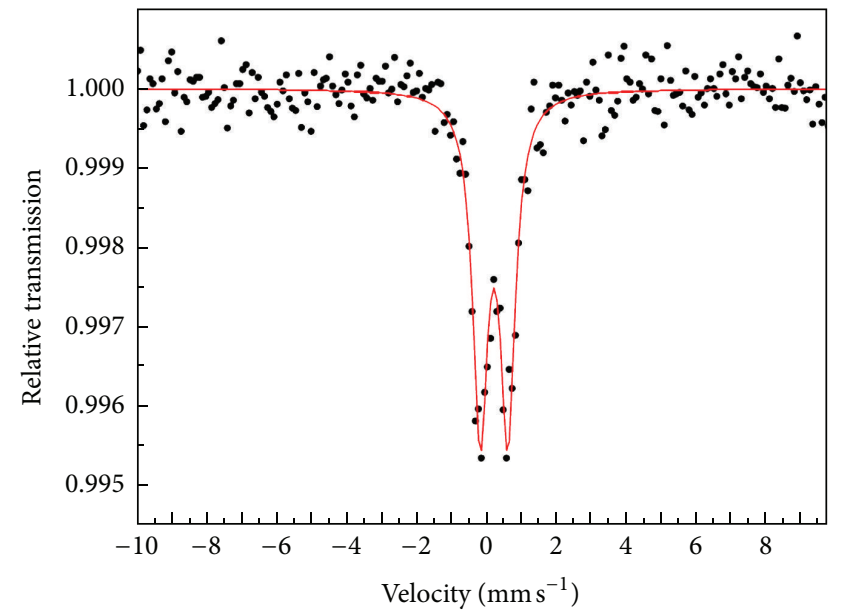

Figure 1: The room Temperature (295 K) Mössbauer spectrum of $\mathrm{Fe}(\mathrm{III})(\text { curc })_{3}$.

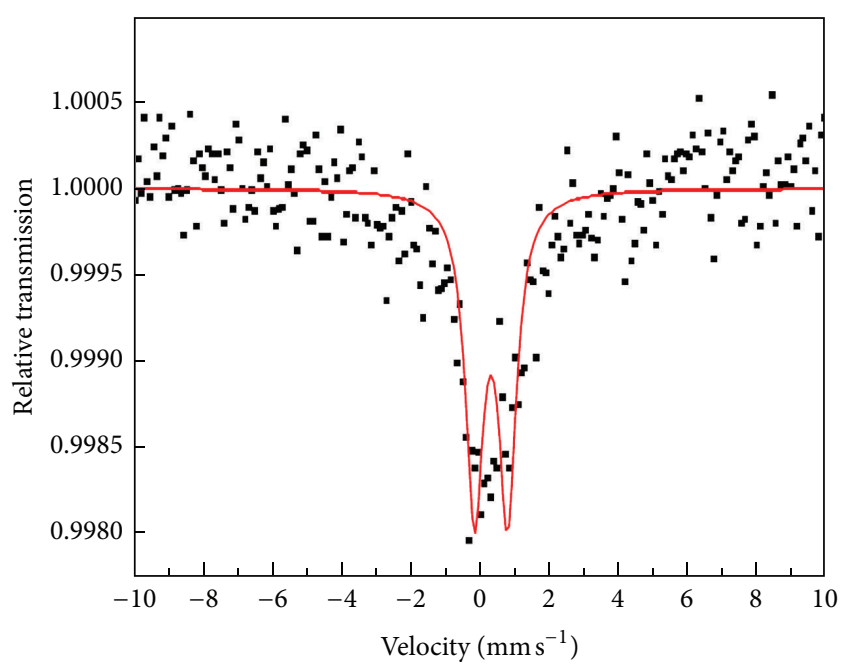

Figure 2: The room temperature (295 K) Mössbauer spectrum of the $\mathrm{Fe}(\mathrm{III})(\mathrm{acac})_{3}$.

that was made slightly basic by the addition of few drops of triethylamine. The deep red brown solid product was vacuum filtered, washed with methanol, and dried in vacuum at room temperature overnight. The complex was characterized by elemental analysis, FTIR (supporting information), and Mössbauer spectroscopy, Figure 2 and Table 1. The elemental analytical data are consistent with the formulation: $\mathrm{Fe}\left[\mathrm{C}_{21} \mathrm{H}_{19} \mathrm{O}_{6}\right]_{3} \cdot 2 \mathrm{H}_{2} \mathrm{O}$. found, (calc): $\mathrm{C} \%, 63.02$, (63.36); $\mathrm{H} \%$, 5.06, (5.10); O\%, 26.20, (26.79); Fe\%, 5.02, (4.68). 
TABLE 2: Surviving fraction of cancer cells at various concentrations $(\mu \mathrm{g} / \mathrm{mL})$.

\begin{tabular}{|c|c|c|c|c|c|c|}
\hline \multirow{2}{*}{ Cancer line } & \multirow{2}{*}{ Compound } & \multicolumn{5}{|c|}{ Concentration } \\
\hline & & 0 & 5 & 12.5 & 25 & 50 \\
\hline \multirow{3}{*}{ НCT-116 } & Dox & 1.000000 & 0.321921 & 0.255892 & 0.170503 & 0.184712 \\
\hline & Curcumin & 1.000000 & 0.337999 & 0.210925 & 0.210925 & 0.298885 \\
\hline & $\mathrm{Fe}(\operatorname{curc})_{3}$ & 1.000000 & 0.634077 & 0.596687 & 0.248749 & 0.229726 \\
\hline \multirow{3}{*}{ HEPG2 } & Dox & 1.000000 & 0.340080 & 0.301258 & 0.193985 & 0.155926 \\
\hline & Curcumin & 1.000000 & 0.293962 & 0.149182 & 0.236437 & 0.299768 \\
\hline & $\mathrm{Fe}(\text { curc })_{3}$ & 1.000000 & 0.969865 & 0.600591 & 0.228678 & 0.312434 \\
\hline \multirow{3}{*}{ Hela } & Dox & 1.000000 & 0.203353 & 0.190643 & 0.080675 & 0.096833 \\
\hline & Curcumin & 1.000000 & 0.260466 & 0.164231 & 0.186826 & 0.323229 \\
\hline & $\mathrm{Fe}(\text { curc })_{3}$ & 1.000000 & 0.933095 & 0.679533 & 0.226367 & 0.363397 \\
\hline \multirow{3}{*}{ MCF7 } & Dox & 1.000000 & 0.194273 & 0.171715 & 0.185526 & 0.201330 \\
\hline & Curcumin & 1.000000 & 0.140455 & 0.118242 & 0.145352 & 0.250152 \\
\hline & $\mathrm{Fe}(\text { curc })_{3}$ & 1.000000 & 0.869626 & 0.737578 & 0.357802 & 0.248558 \\
\hline
\end{tabular}

\section{Results and Discussion}

The Mössbauer effect is the most reliable technique to identify the oxidation state of iron ions in complexes. The Mössbauer absorption spectrum of the as-prepared curcumin-iron(III) complexes is of similar pattern showing a quadrupole-split doublet of equal intensities and chemical isomer shifts characteristic of octahedral high-spin iron(III) [12-15], Figures 1 and 2 and Table 1.

The absence of any magnetic components at liquid nitrogen temperature rules out the existence of magnetic relaxation. There is no Mössbauer effect evidence that $\mathrm{Fe}(\mathrm{III})$ is reduced to $\mathrm{Fe}$ (II) in the presence of curcumin as reported in the literature [8]. The $\mathrm{Fe}^{2+}$ ion, if present, should show a doublet having an isomer shift of $1.2 \mathrm{~mm} / \mathrm{s}$ and a quadrupole of $2.9 \mathrm{~mm} / \mathrm{s}$ [14].

The FTIR and ${ }^{1} \mathrm{H}$ NMR spectroscopic measurements have confirmed the enol form of curcumin (supporting information). The FTIR spectrum of Fe(III)(curc) ${ }_{3}$ complex lost the $3423 \mathrm{~cm}^{-1}$ band assigned to $\nu(\mathrm{O}-\mathrm{H})$ of the enol form with the persistence of the phenolic $(\mathrm{OH})$ group vibrational band strongly indicating that it is not coordinated to the metal ion (supporting information). The chemistry of curcumin solution system is $\mathrm{pH}$ dependent. Tonnesen and Karlsen [16] have studied the stability of curcumin in the $\mathrm{pH}$ range from 1 to 11 . They have postulated that curcumin is in equilibrium between three forms, that is, $\mathrm{H}_{3} \mathrm{Curc} ; \mathrm{H}_{2} \mathrm{Curc}^{-}$; $\mathrm{HCurc}^{2-}$, at $\mathrm{pH}$ area 8.2-8.5. They reported a $50 \%$ degradation of curcumin in a $0.1 \% \mathrm{NaOH}$ solution. Pineda et al. [17] measured three acidity constants for curcumin. The one corresponding to the equilibrium $\mathrm{H}_{3} \mathrm{Curc} \leftrightarrow \mathrm{H}_{2} \mathrm{Curc}^{-}+\mathrm{H}^{+}\left[\mathrm{p} K_{a}=\right.$ 8.38] was attributed to the acetylacetone-type group. Such a dependence of curcumin system on $\mathrm{pH}$ of solution means that the $\mathrm{H}^{+}$ion is involved in reaction mechanism. However, there are some controversies on which proton(s) is involved. While Tonnesen et al. [18] concluded that complex formation between curcumin and iron and the reduction of $\mathrm{Fe}^{3+}$ to $\mathrm{Fe}^{2+}$ in the presence of curcumin are independent of the phenolic hydroxyl groups in the curcumin molecule, Barclay et al. [19] reported that synthetic nonphenolic curcumin exhibited no

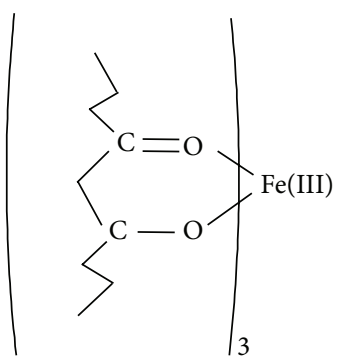

FIGURE 3: Bidentate coordination of curcumin ligand to Fe(III) ion.

antioxidant activity deducing that the $\mathrm{H}$ atoms are donated from the phenolic groups. On the other hand, Jovanovic et al. [20] suggested the release of $\mathrm{H}$ atoms from $\mathrm{CH}_{2}$ group.

Accordingly, we envisage that the number of protons released by the curcumin enol form determines the type of product. Hence, the three curcumin ligands are coordinated to the iron(III) ion in a bidentate fashion forming the octahedral geometry indicated by the measured Mössbauer parameters, Figure 3.

The antitumor activity of such an established octahedral high-spin iron(III) complex was tested against four cancer cell lines, that is, MCT-7, HepG-2, Hela, and HCT-116. Their activities were compared to doxorubicin (DOX) and pure curcumin. The calculated $\mathrm{IC}_{50}$ values indicated that metal complexation inhibits the cytotoxicity of curcumin, Tables 2 and 3. Table 2 presents the survival fractions of the four cancer cell lines at different concentrations of inhibitors, and the calculated $\mathrm{IC}_{50}$ values are presented in Table 3 .

Curcumin alone showed higher antioxidant effect towards all four tumor cell lines at $\mathrm{IC}_{50}$ values of 3.02 (MCF7), 3.43 (HepG2), 3.43 (Hela), and 3.81 (HCT-116) $\mu \mathrm{g} \mathrm{mL}^{-1}$, than both curcumin-iron(III) complexes (see supporting information). These results are in contrast with the reported concept of synergistic enhancement of ligand effects by combination with ions $[5-7,21-23]$. One may relate the lower cytotoxicity of the curcumin-iron complexes compared to curcumin alone to the fact that the central carbon atom 
TABLE 3: Cytotoxicity on cancer cell lines.

\begin{tabular}{lcccc}
\hline & & $\mathrm{IC}_{50}$ value $(\mu \mathrm{g} / \mathrm{mL})$ & & \\
\hline & MCF-7 & Cancer cells & Hela & HCT-116 \\
\hline DOX & 2.97 & HepG-2 & 3.64 & 3.743 \\
Curcumin & 3.02 & 4.57 & 3.43 & 3.81 \\
Fe(curc) & 20.4 & 3.43 & 17.6 & 16 \\
Fe(acac) & 22.0 & 15.8 & 21.3 & 21.0 \\
\hline
\end{tabular}

with the labile hydrogen is locked and unable to produce oxyradicals unless the curcumin ligand dissociates from the complex. It is more likely that the keto-enol function but not the phenol $\mathrm{OH}$ group directs curcumin cytotoxic behavior.

It is worth mentioning that metal acetates or chlorides are the reagents used by research workers for the synthesis of curcumin-metal complexes although Pineda et al. [17] did not specify the iron salt employed in their study.

Then, one cannot rule out at this stage the role of the oxidizing nitrate groups in inhibiting the reduction of $\mathrm{Fe}^{3+}$ ions by curcumin. It is the reaction suggested by Pineda et al. [17] to take place prior to complex formation.

The $\mathrm{IC}_{50}$ values of both iron complexes, being of comparable values, could be attributed to the antioxidant potential of iron(III) ion. Hence, one can conclude that the diketone system of curcumin appears to be the part of the curcumin molecule involved in the scavenging of oxygen radicals.

\section{Conflict of Interests}

The authors declare that they have no conflict of interests arising from any financial relation with the commercial identity mentioned in this paper.

\section{Acknowledgment}

This project was supported by King Saud University, Deanship of Scientific Research, College of Science, Research Center.

\section{References}

[1] R. H. Liu, "Potential synergy of phytochemicals in cancer prevention: mechanism of action," Journal of Nutrition, vol. 134, no. 12, pp. 3479S-3485S, 2004.

[2] B. K. Adams, E. M. Ferstl, M. C. Davis et al., "Synthesis and biological evaluation of novel curcumin analogs as anticancer and anti-angiogenesis agents," Bioorganic and Medicinal Chemistry, vol. 12, no. 14, pp. 3871-3883, 2004.

[3] E. R. Hahm, Y. S. Gho, S. Park, C. Park, K. W. Kim, and C. H. Yang, "Synthetic curcumin analogs inhibit activator protein1 transcription and tumor-induced angiogenesis," Biochemical and Biophysical Research Communications, vol. 321, no. 2, pp. 337-344, 2004.

[4] S. V. Jovanovic, C. W. Boone, S. Steenken, M. Trinoga, and R. B. Kaskey, "How curcumin works preferentially with water soluble antioxidants," Journal of the American Chemical Society, vol. 123, no. 13, pp. 3064-3068, 2001.
[5] K. H. Thompson, K. Böhmerle, E. Polishchuk et al., "Complementary inhibition of synoviocyte, smooth muscle cell or mouse lymphoma cell proliferation by a vanadyl curcumin complex compared to curcumin alone," Journal of Inorganic Biochemistry, vol. 98, no. 12, pp. 2063-2070, 2004.

[6] S. Zhang, C. Tu, and X. Wang, "Novel C ytotoxic Copper(II) complexes of 8-aminoquinoline derivatives: crystal structure and different reactivity towards Glu tathioneInorg," European Journal of Chemistry, vol. 98, pp. 4028-4035, 2004.

[7] S. Dutta, A. Murugkar, N. Gandhe, and S. Padhye, "Enhanced antioxidant activities of metal conjugates of Curcumin derivatives," Metal-Based Drugs, vol. 8, no. 4, pp. 183-188, 2001.

[8] H. H. Tonnesen and J. V. Greenhill, "Studies on curcumin and curcuminoids. XXII: curcumin as a reducing agent and as a radical scavenger," International Journal of Pharmaceutics, vol. 87, no. 1-3, pp. 79-87, 1992.

[9] K. K. Sharma, S. Chandra, and D. K. Basu, "Synthesis and antiarthritic study of a new orally active diferuloyl methane (curcumin) gold complex," Inorganica Chimica Acta, vol. 135, no. 1, pp. 47-48, 1987.

[10] A. Hantzsch and C. H. Desch, Annalen, vol. 1, American Chemical Society, Washington, DC, USA, 1902.

[11] J. Josepg, H. A. C. Mckay, and E. J. W. Verwey, “The infrared spectra of metal acetylacetonates in the sodium chloride region," Journal of Inorganic and Nuclear Chemistry, vol. 5, pp. 295-303, 1958.

[12] M. I. Khalil and A. I. AL-Wassil, "The Nature of iron moiety, a mossbauer spctroscopic investigation," Journal of the Serbian Chemical Society, vol. 3, pp. 19-25, 1999.

[13] M. W. Hisham and F. J. Berry, "The influence of ball milling and subsequent calcination on the formation of $\mathrm{LiFeO}_{2}$," Journal of Materials Science, vol. 37, no. 21, pp. 4621-4625, 2002.

[14] E. Murad and R. M. Taylor, "The Mossbauer spectra of hydroxycarbonate green rusts," Clay Minerals, vol. 19, no. 1, pp. 77-83, 1984.

[15] C. W. Childs and J. H. Johnston, "Mossbauer spectra of proto-ferrihydrite at 77K and 295K," Australian Journal of Soil Research, vol. 18, pp. 245-250, 1980.

[16] H. H. Tonnesen and J. Karlsen, "Studies on curcumin and curcuminoids," Zeitschrift für Lebensmittel-Untersuchung und Forschung, vol. 180, pp. 402-404, 1985.

[17] M. B. Pineda, M. T. R. Silva, M. R. Romo, E. G. Verqara, and A. R. Hennandez, "Spectroscopica," Chemica Acta A, vol. 60, no. 5, pp. 1091-1097, 2004.

[18] H. H. Tonnesen, J. Karlsenand, and G. B. Henegouwer, "Studies on curcumin and curcuminoids VIII. Photochemical stability of curcumin," Zeitschrift für Lebensmittel-Untersuchung undForschung, vol. 183, no. 2, pp. 116-122, 1986.

[19] L. R. C. Barclay, M. R. Vinqvist, K. Mukai et al., "On the antioxidant mechanism of curcumin: classical methods are 
needed to determine antioxidant mechanism and activity," Organic Letters, vol. 2, no. 18, pp. 2841-2843, 2000.

[20] S. V. Jovanovic, S. Steenken, C. W. Boone, and M. G. Simic, "H-atom transfer is a preferred antioxidant mechanism of curcumin," Journal of the American Chemical Society, vol. 121, no. 41, pp. 9677-9681, 1999.

[21] X. Sheng, X. M. Lu, Y. T. Chen et al., "Synthesis, DNAbinding, cleavage, and cytotoxic activity of new 1,7-dioxa-4,10diazacyclododecane artificial receptors containing bisguanidinoethyl or diaminoethyl double side arms," Chemistry, vol. 13, no. 34, pp. 9703-9712, 2007.

[22] A. Valentini, F. Conforti, A. Crispini et al., "Synthesis, oxidant properties, and antitumoral effects of a heteroleptic palladium(II) complex of curcumin on human prostate cancer cells," Journal of Medicinal Chemistry, vol. 52, pp. 484-491, 2009.

[23] G. Federici, S. Bernadini, and D. Pucci, "Effects of a heteroleptic palladium (II) comple $\mathrm{x}$ of curcumin on human prostate cancer ghedini," Journal of Solid State Chemistry, vol. 160, pp. 230-236, 2002. 

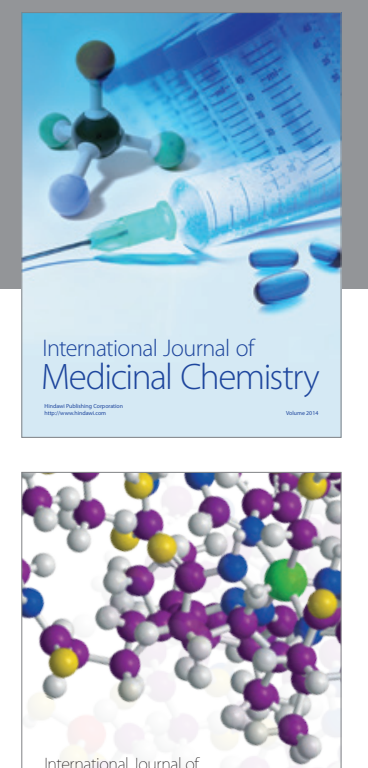

\section{Carbohydrate} Chemistry

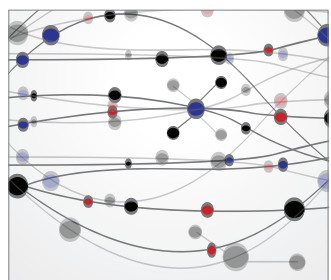

The Scientific World Journal
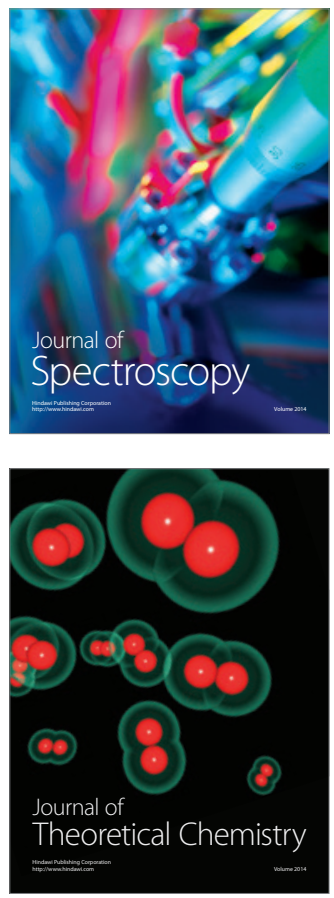
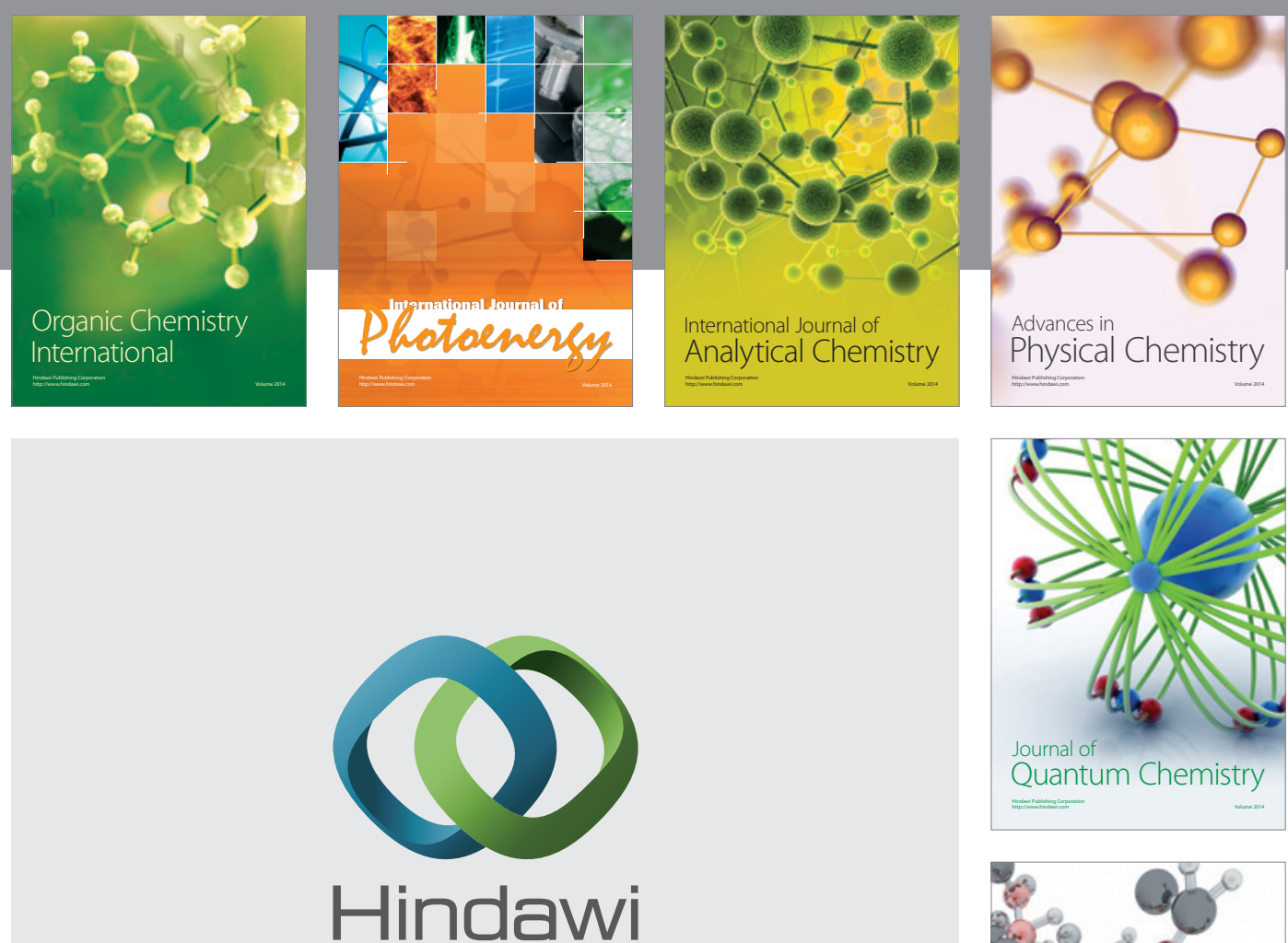

Submit your manuscripts at

http://www.hindawi.com

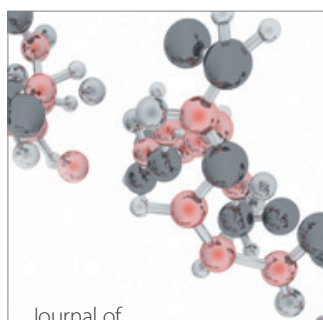

Analytical Methods

in Chemistry

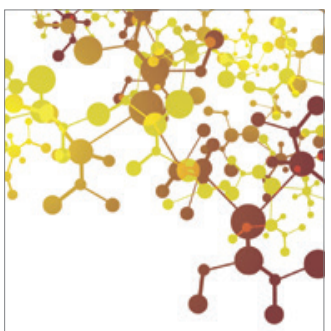

Journal of

Applied Chemistry

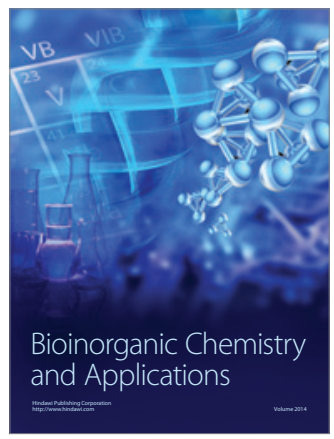

Inorganic Chemistry
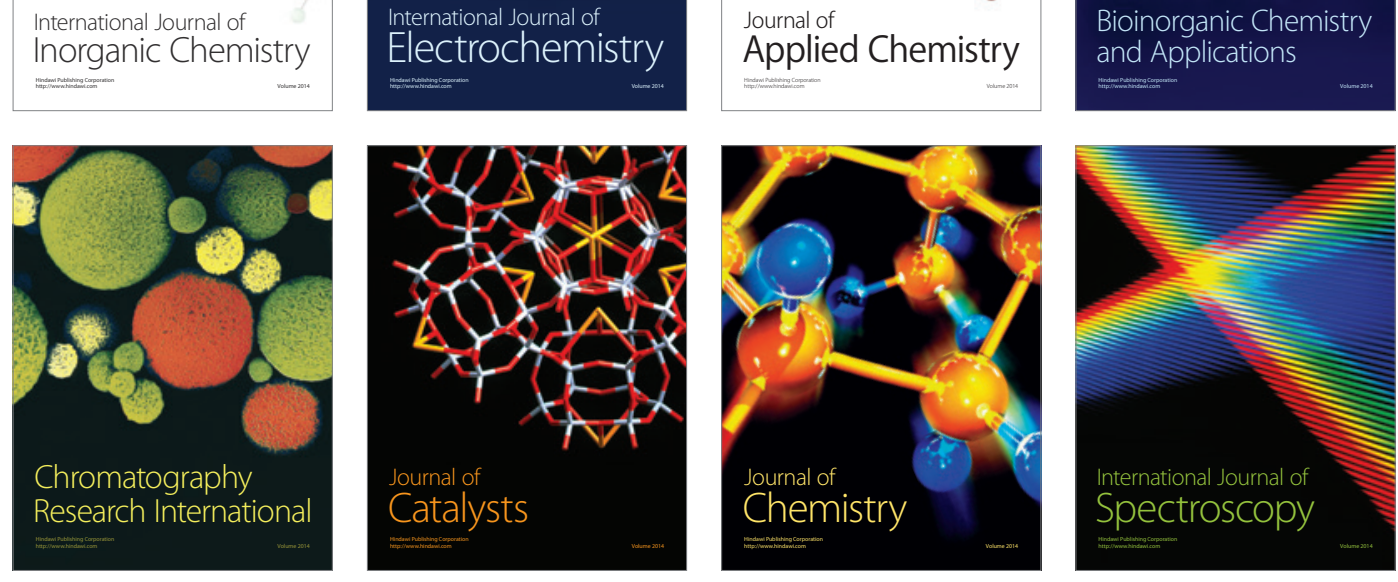